\title{
Investigation of discontinuously reinforced aluminium metal matrix composite fabricated by two different micron ceramic reinforcements $\left(\mathrm{ZrSiO}_{4}, \mathrm{~B}_{4} \mathrm{C}\right)$ : comparative study
}

\author{
K. Shirvanimoghaddam ${ }^{*}$, M. Karbalaei Akbari², H. Abdizadeh ${ }^{3}$, A. H. Pakseresht ${ }^{4}$, F. Abdi ${ }^{5}$, \\ A. Shahbazkhan ${ }^{6}$ \\ ${ }^{1}$ Institute for Frontier Materials, Deakin University, 75 Pigdons Rd., Waurn Ponds, Victoria 3216, Australia \\ ${ }^{2}$ Faculty of Metallurgical and Materials Engineering, Semnan University, P.O. Box 35131-19111, Semnan, Iran \\ ${ }^{3}$ School of Metallurgy and Materials Engineering, University of Tehran, P.O. Box 11365-4563, Tehran, Iran \\ ${ }^{4}$ Materials and Energy Research Centre, P.O. Box 31787-316, Karaj, Iran \\ ${ }^{5}$ Islamic Azad University, South Tehran Branch, P.O. Box 15655-461, Tehran, Iran \\ ${ }^{6}$ Department of Materials Science and Engineering, Sharif University of Technology, P.O. Box 11365-9466, Tehran, Iran
}

Received 31 July 2013, received in revised form 30 June 2014, accepted 23 October 2014

\begin{abstract}
The focus of this research is on the fabrication of aluminium- $\mathrm{B}_{4} \mathrm{C}$ and aluminium- $\mathrm{ZrSiO}{ }_{4}$ composites by vortex method as a liquid phase process of metal matrix composites. SEM observations show that reinforcement particles are dispersed homogeneously throughout the aluminium matrix. Density, mechanical properties such as hardness and tensile strength of $\mathrm{Al}$ base MMCs containing different volume fractions (5, 10 and $15 \%$ ) of micro-reinforcements are examined separately and compared with those of monolithic aluminium. Results show that mechanical properties of samples are noticeably higher than those of the monolithic aluminium. The optimum amount of reinforcement in this study was found to be $5 \%$ and 5 $10 \%$ for $\mathrm{ZrSiO}_{4}$ and $\mathrm{B}_{4} \mathrm{C}$, respectively. The highest ultimate tensile strength of composites is $187 \mathrm{MPa}$ for aluminium- $5 \% \mathrm{~B}_{4} \mathrm{C}$ in comparison to 223 for aluminium- $5 \% \mathrm{ZrSiO}_{4}$. Also, hardness data show a significant increase by adding reinforcements and reached a zenith of $75 \mathrm{HB}$ for aluminium- $\mathrm{ZrSiO}_{4}$ and $79 \mathrm{HB}$ for aluminium- $\mathrm{B}_{4} \mathrm{C}$.
\end{abstract}

$\mathrm{K}$ e y w or d s: aluminium matrix composites, reinforcement, $\mathrm{ZrSiO}_{4}, \mathrm{~B}_{4} \mathrm{C}$

\section{Introduction}

Metal matrix composites (MMCs) are materials of choice for a number of significant applications in aerospace and automobile industries. Aluminium base alloys are one of the most widely used materials in MMCs as a matrix from research and industrial outlook [1]. This is owing to their unique properties like light weight, superb yield and tensile strength, high specific modulus, low thermal expansion coefficient, and good wear resistance [2-3]. Continuously reinforced composites offer better specific strength in preferred direction than other composites; however, the mass production of high strength fibres is not cost effective and leads to limitation in their industrial applications. Discontinuously reinforced aluminium
(DRA) alloy metal matrix composites (MMCs) based on particulate, whisker or short-fibre reinforcements compete tent of contesting with popular aluminium and titanium alloys and organic matrix composites. Metal matrix composites possess a very superior quality in comparison to monolithic materials and this is a driving force for researchers to work in this field, especially in last two decades [4-10]. In particular, the DRA MMCs are a preferred choice and offer a list of advantages better than a pure aluminium alone such as a noticeable increase in ultimate tensile strength, at least 30 to $100 \%$ increase in stiffness and superior wear resistance collated with the unreinforced aluminium alloys [11-17]. Moreover, these composites are amendable to the manufacturing and characterization methods used for the formal unreinforced peers. The

*Corresponding author: tel.: +61 405278173; e-mail address: Kamyar.shirvanimoghaddam@deakin.edu.au 
Table 1. Chemical composition of matrix (aluminium A356.1)

\begin{tabular}{lcccccccccccc}
\hline Element & $\mathrm{Al}$ & $\mathrm{Si}$ & $\mathrm{Fe}$ & $\mathrm{Cu}$ & $\mathrm{Mn}$ & $\mathrm{Mg}$ & $\mathrm{Zn}$ & $\mathrm{Ti}$ & $\mathrm{Cr}$ & $\mathrm{Ni}$ & $\mathrm{Pb}$ & $\mathrm{Sn}$ \\
\hline Percentage & 91.73 & 7.23 & 0.32 & 0.18 & 0.02 & 0.38 & 0.05 & 0.01 & $<0.01$ & 0.05 & 0.02 & 0.01 \\
\hline
\end{tabular}

Ta ble 2. Chemical composition of reinforcement $\left(\mathrm{ZrSiO}_{4}\right.$ particle)

\begin{tabular}{lcccccccc}
\hline Element & Zirconia & Silica & Titanium dioxide & Ferric oxide & Alumina & Lime & Magnesia & Phosphoric anhydride \\
\hline Percentage & 66.34 & 30 & 0.26 & 0.11 & 0.9 & 0.14 & 0.22 & 0.13 \\
\hline
\end{tabular}

Ta ble 3. Chemical composition of reinforcement (boron carbide particle)

\begin{tabular}{lccccc}
\hline Element & Total boron & Total carbon & Total iron & Total B + C & Other \\
\hline Percentage & $77 / 5$ & $21 / 5$ & $0 / 2$ & 99 & $0 / 8$ \\
\hline
\end{tabular}

Ta b le 4. List of processing parameters

\begin{tabular}{|c|c|c|c|c|c|c|}
\hline Volume fraction of reinforcement & $5 \% \mathrm{~B}_{4} \mathrm{C}$ & $10 \% \mathrm{~B}_{4} \mathrm{C}$ & $15 \% \mathrm{~B}_{4} \mathrm{C}$ & $5 \% \mathrm{ZrSiO}_{4}$ & $10 \% \mathrm{ZrSiO}_{4}$ & $15 \% \mathrm{ZrSiO}_{4}$ \\
\hline Sample No. & 1 & 2 & 3 & 4 & 5 & 6 \\
\hline Processing temperature $\left({ }^{\circ} \mathrm{C}\right)$ & 750 & 750 & 750 & 750 & 750 & 750 \\
\hline No. of melting steps & 1 & 1 & 2 & 2 & 3 & 3 \\
\hline $\begin{array}{l}\text { Distance to melting point of pure } \\
\text { aluminium (approximately) }\left({ }^{\circ} \mathrm{C}\right)\end{array}$ & 100 & 100 & 100 & 100 & 100 & 100 \\
\hline Total stirring time $(\mathrm{min})$ & $20-24$ & $22-26$ & $24-28$ & $20-24$ & $22-26$ & $24-28$ \\
\hline Mixing time $(\min )$ & $5-7$ & $7-9$ & $9-11$ & $5-7$ & $7-9$ & $9-11$ \\
\hline Blade angle & $45^{\circ}$ & $45^{\circ}$ & $45^{\circ}$ & $45^{\circ}$ & $45^{\circ}$ & $45^{\circ}$ \\
\hline No. of blades & 3 & 3 & 3 & 3 & 3 & 3 \\
\hline Position of stirrer in the melt & $\begin{array}{c}\text { up to } 3 / 4 \\
\text { depth }\end{array}$ & $\begin{array}{c}\text { up to } 3 / 4 \\
\text { depth }\end{array}$ & $\begin{array}{l}\text { up to } 3 / 4 \\
\text { depth }\end{array}$ & $\begin{array}{c}\text { up to } 3 / 4 \\
\text { depth }\end{array}$ & $\begin{array}{c}\text { up to } 3 / 4 \\
\text { depth }\end{array}$ & $\begin{array}{c}\text { up to } 3 / 4 \\
\text { depth }\end{array}$ \\
\hline
\end{tabular}

hardness, moduli and tensile strength of metal matrix composites are larger than those of typical aluminium and titanium alloys and only marginally less than those of most popular steel. It seems that this improvement in elastic modules affects yield strength and ultimate tensile strength of up to $60 \%[14,15$, $18,19]$. Furthermore, the DRA metal matrix composites originated on particulate reinforcements are noteworthy because they will be processed with properties that are near isotropic in three orthogonal directions or in a plane [20]. Also, applying non-expensive methods such as stir casting as a main way of MMCs-particulate reinforced fabrication method can lead to production of a wide range of product forms, making them relatively inexpensive compared with the composites that are reinforced with continuous fibres, whiskers or filaments [21]. Aluminium matrix composites have obtained a great interest, because they combine high corrosion resistance, low weight, low cost, high specific strength and perfect wear resistance [22-
25]. Aluminium matrix composites have been investigated by many researchers [26-33]. However, $\mathrm{B}_{4} \mathrm{C}$ and $\mathrm{ZrSiO}_{4}$ reinforced aluminium matrix composite has not attracted enough attention. Due to high hardness and excellent modulus of $\mathrm{ZrSiO}_{4}$ and $\mathrm{B}_{4} \mathrm{C}$, it is used in the present investigation.

\section{Experiments}

Aluminium A356.1 billets is applied as a matrix in this project and Table 1 shows the chemical composition of this material.

$\mathrm{ZrSiO}_{4}$ and $\mathrm{B}_{4} \mathrm{C}$ powder are used as a reinforcement phase (Tables 2,3). Zirconium silicate and boron carbide powders (with spherical shape) have a mean particle size of 1 micron and there is not any physical bond between particles before pouring into molten aluminium (no whisker or filament). Aluminium is liquated inside a graphite crucible in electric furnace at 
$750^{\circ} \mathrm{C}$. A graphite stirrer poked the melt aluminium at a fixed rotation speed of $400 \mathrm{rpm}$. About $3 \mathrm{~g}$, sodium hexa fluoro aluminate $\left(\mathrm{Na}_{3} \mathrm{AlF}_{6}\right)$ is plunged into the melt to improve the foundry condition and hinder from slag establishment. Stirring is continued for a few minutes. Then 5, 10 and 15 vol.\% reinforcement is added to molten aluminium separately in different processing conditions (Table 4). Then molten composite is poured inside a metallic mold. Metallic mold is used to curb unwanted conditions and to enhance the solidification speed. For achieving a best dispersion of reinforcement in aluminium and barricade to go to slag, reinforcement particles are placed in aluminium foils and then are infiltrated in liquid. The molten composites were solidificated inside metallic mold.

XRD patterns of composite samples are obtained from PW-1800 Philips, XRD results and the microstructures behaviour of samples are determined by Scanning Electron Microscopy (CAMSCAN-MV2300 MODEL, OXFORD). Specimens were polished and etched using Keller solution. Hardness tests results were extracted from a Brinell spherical hardness testing machine (GMAH Wolpert). Applying of the load of $10 \mathrm{kN}$ with a loading time of $260 \mathrm{~s}$ is the next step of the tests. Heating process of bulk aluminium is a continuous process that increases the temperature of solid aluminium to the exactly $750^{\circ} \mathrm{C}$. This is a onestep process for samples of no. 1 and 4 . After this step, for producing samples 2 and 5 , this is the same process to heat up to $750^{\circ} \mathrm{C}$ and then for better distribution of reinforcements, mixing time is increased. In a similar way, for samples by $15 \%$ reinforcement, four minutes additional time is required to achieve better distribution of $\mathrm{ZrSiO}_{4}$ or $\mathrm{B}_{4} \mathrm{C}$ in molten aluminium (samples $3,6)$.

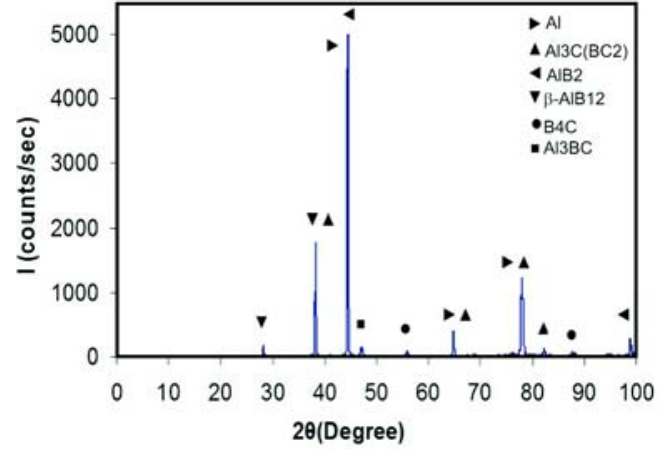

Fig. 1. XRD pattern of $\mathrm{Al}-5 \% \mathrm{~B}_{4} \mathrm{C}$ composite casted at $750{ }^{\circ} \mathrm{C}$.

\section{Results and discussion}

\subsection{Study of chemical composition of MMCs samples}

Figure 1 shows the XRD pattern of aluminium$\mathrm{B}_{4} \mathrm{C}$ samples which was produced at $750^{\circ} \mathrm{C}$. It can be seen that $\mathrm{B}_{4} \mathrm{C}$ and aluminium are present in the samples. It can be concluded that along with $\mathrm{B}_{4} \mathrm{C}$, some parts of $\mathrm{B}_{4} \mathrm{C}$ do not absorb in the melt. It seems that except of $\mathrm{B}_{4} \mathrm{C}$, a lot of different compounds of aluminium with reinforcement were produced there $\left(\mathrm{Al}_{3} \mathrm{C}\left(\mathrm{BC}_{2}\right), \mathrm{AlB}_{2}, \mathrm{Al}_{3} \mathrm{BC}, \beta-\mathrm{AlB}_{12}\right)$. So this kind of interactions between metal matrix and reinforcement may occur and has some unfavourable impact on mechanical and physical behaviour of metal matrix composite samples.

Figure 2 shows the XRD pattern of aluminium$\mathrm{ZrSiO}_{4}$ samples produced at $750^{\circ} \mathrm{C}$. It can be seen that $\mathrm{ZrSiO}_{4}$ and aluminium are present in the samples

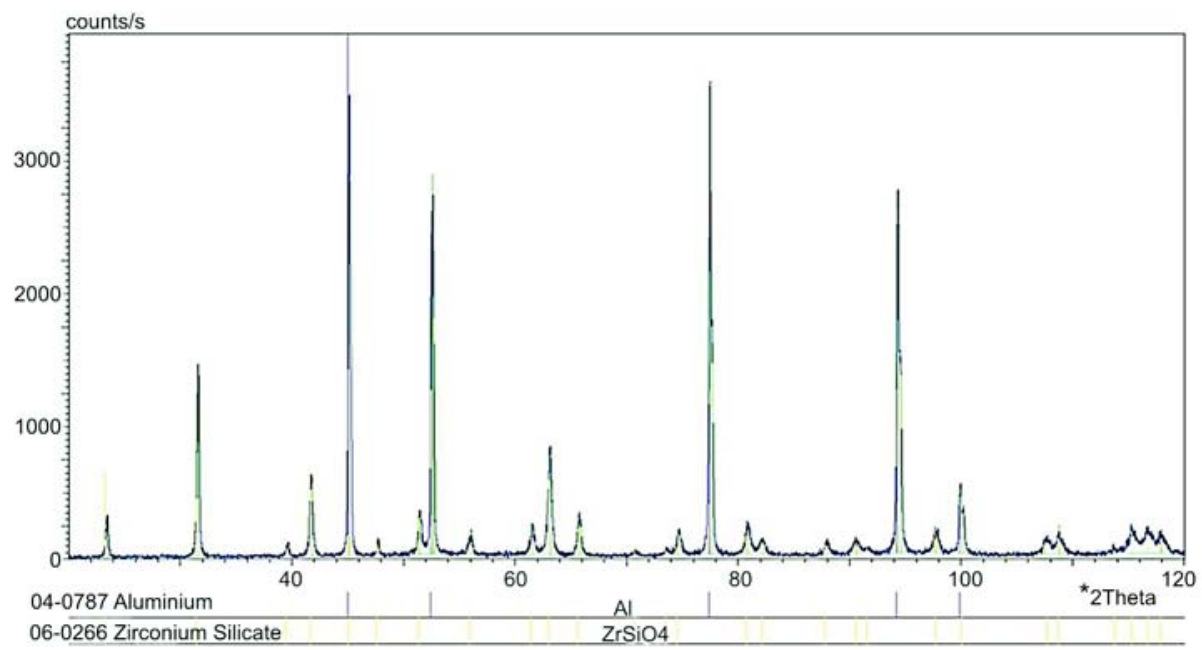

Fig. 2. XRD pattern of $\mathrm{Al}-5 \% \mathrm{ZrSiO}_{4}$ composite casted at $750{ }^{\circ} \mathrm{C}$. 

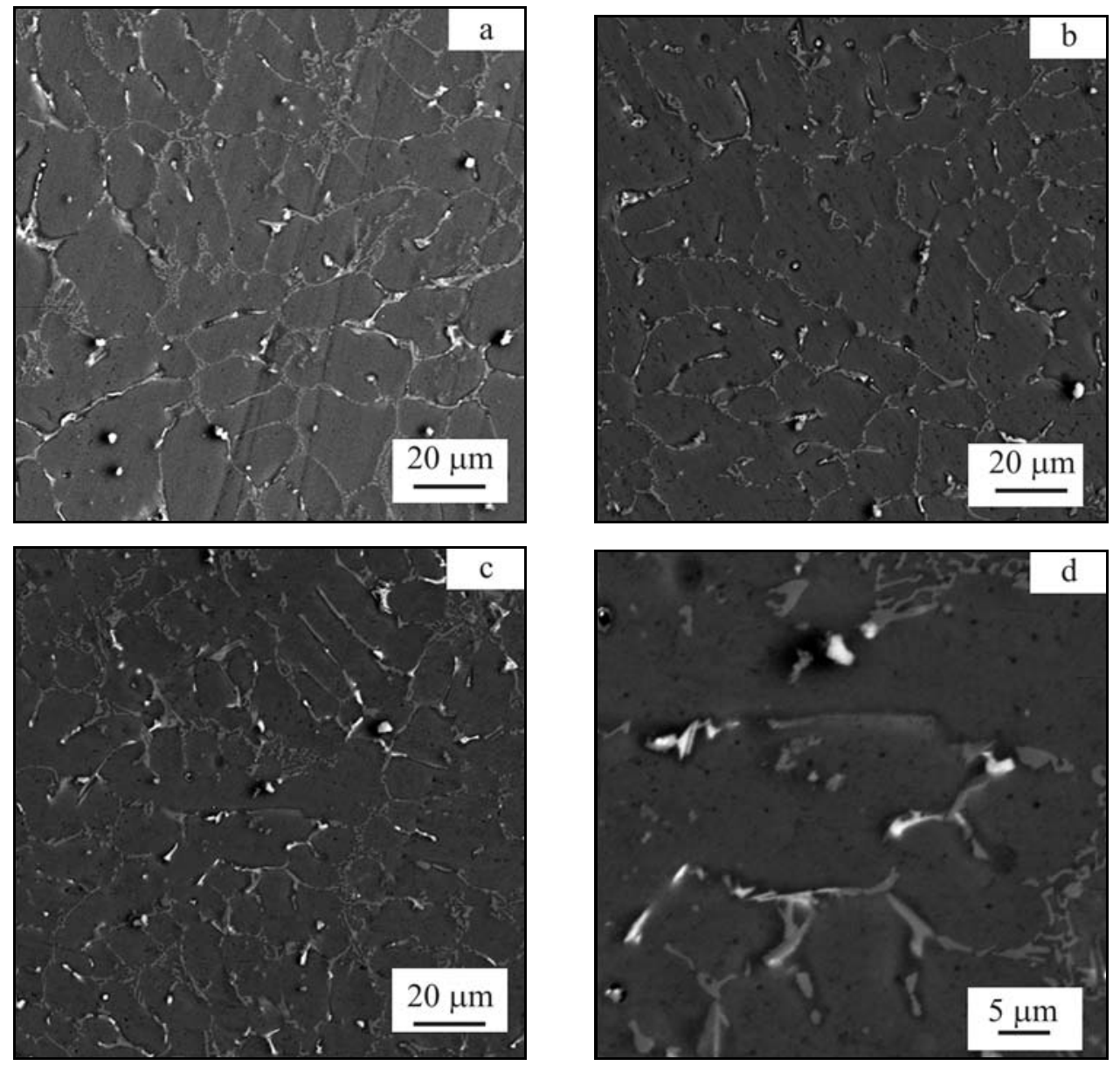

Fig. 3. SEM micrographs of aluminium- $\mathrm{B}_{4} \mathrm{C}$ composite casted at $750^{\circ} \mathrm{C}$ : (a) $\mathrm{Al}-5 \% \mathrm{~B}_{4} \mathrm{C}$, (b) $\mathrm{Al}-10 \% \mathrm{~B}_{4} \mathrm{C}$, (c) $\mathrm{Al}-15 \% \mathrm{~B}_{4} \mathrm{C}$, (d) $\mathrm{Al}-15 \% \mathrm{~B}_{4} \mathrm{C}$ (high magnification).

and there is not any unwanted reaction between base metal and reinforcement.

\subsection{Study of microstructural characterization of MMCs samples}

Figures 3 and 4 show the SEM micrograph of the produced composites. Figures $3 \mathrm{a}-\mathrm{c}$ show that $\mathrm{B}_{4} \mathrm{C}$ particles are homogeneously dispersed throughout the samples. The white and dark spots represent $\mathrm{B}_{4} \mathrm{C}$ particles and aluminium, respectively. The amount of the dispersed $\mathrm{B}_{4} \mathrm{C}$ particles in the samples produced at 5 vol.\% is higher than others, it completely depends on their volume fraction of reinforcement. In other samples, the amount of reinforcement is double and triple in order, but their absorption by metal matrix is less than 5 vol.\% $\mathrm{B}_{4} \mathrm{C}$ sample. This could be a cause of high porosity of system in such volume fraction, interring of air and gas and inhibition of their exiting after pouring (due to longer mixing time) or distortion of grain boundaries in higher amount of reinforcement and its effect on absorption. These figures also depict that the homogeneity of particle distribution is approximately similar in different samples. It also can be seen that the interfaces in the specimens which are produced at 5 and 10 vol. $\% \mathrm{~B}_{4} \mathrm{C}$ are perfect and there is less pore or any other deficiency in this region. However, dark spots in Fig. 3d demonstrate the pore existence in the interface of aluminium matrix and $\mathrm{B}_{4} \mathrm{C}$ particles in the samples produced at 15 vol. $\% \mathrm{~B}_{4} \mathrm{C}$ sample. SEM micrographs of the samples also represent that the grain size of aluminium composite decreases with increasing amount of reinforcement. However, it seems that reinforcement particles enhance the number of nucleus and solidification speed.

Figure 4 shows SEM micrograph of aluminium$-\mathrm{ZrSiO}_{4}$ samples casted at $750^{\circ} \mathrm{C}$. Monotonous particle distribution across the sample has a substantial effect on the composite properties, therefore it is an exigent and very important factor in composite processing. Particle clustering and agglomeration could come to pass even in stir casting method, with which particles dispersed monotonously in the melt. In these figures, the grey matrix represents an aluminium matrix and the white spots represent zirconium silicate particles and the black spaces are the porosity. It can be clearly seen that the grain size of the composites samples produced by stir casting technique is almost 

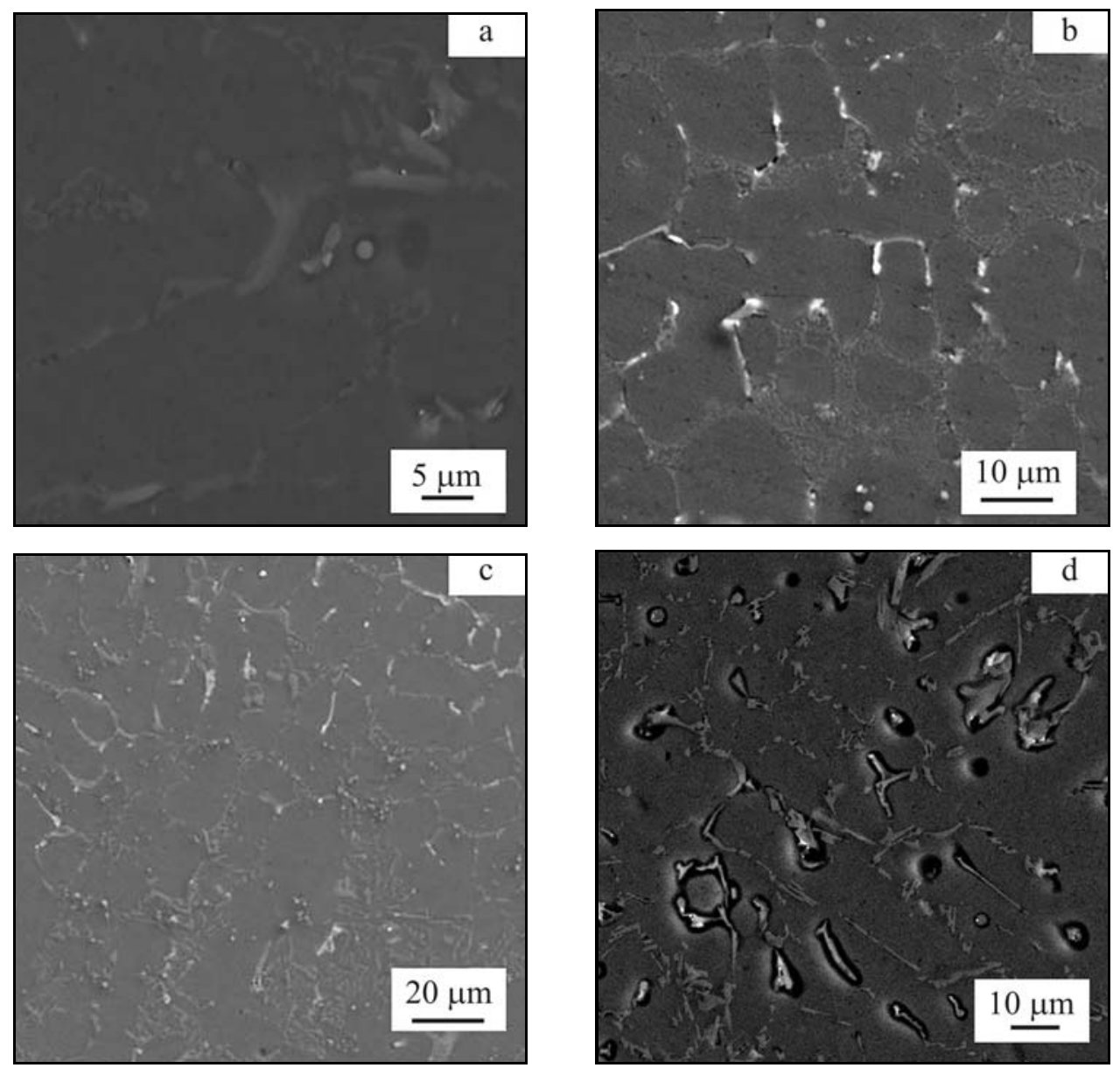

Fig. 4. SEM micrographs of aluminium $-\mathrm{ZrSiO}_{4}$ composite casted at $750{ }^{\circ} \mathrm{C}$ : (a) pure aluminium, (b) $\mathrm{Al}-5 \% \mathrm{ZrSiO}{ }_{4}$, (c) $\mathrm{Al}-10 \% \mathrm{ZrSiO}_{4}$, (d) $\mathrm{Al}-15 \% \mathrm{ZrSiO}_{4}$ (high magnification).

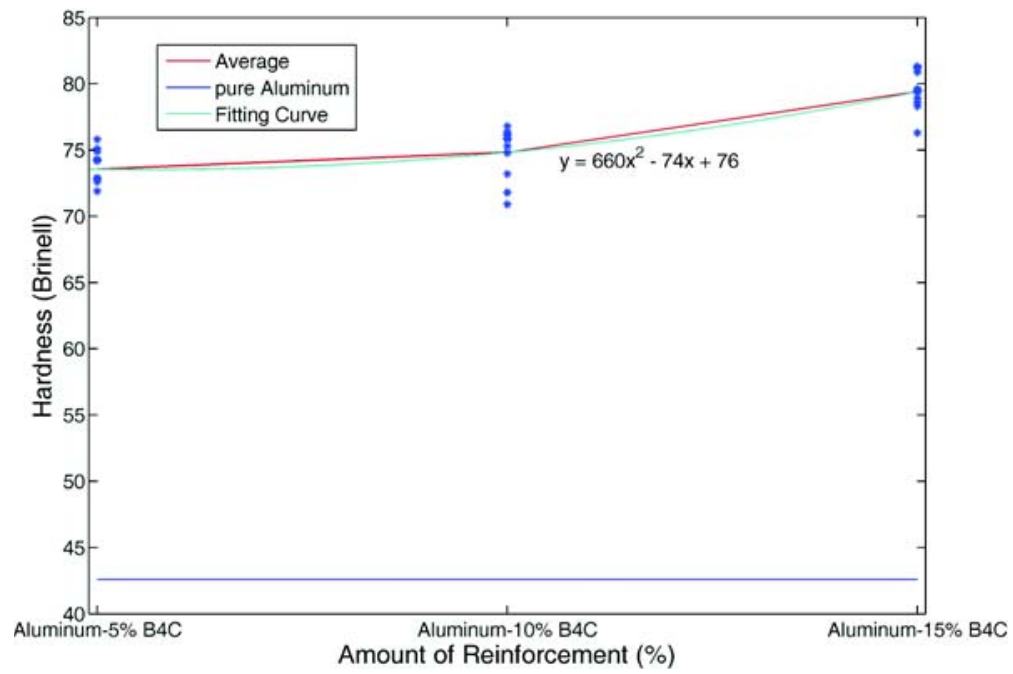

Fig. 5. Hardness variation of $\mathrm{Al}-\mathrm{B}_{4} \mathrm{C}$ composite samples in different amount of $\mathrm{B}_{4} \mathrm{C}$ at $750^{\circ} \mathrm{C}$.

identical and equiaxial. The effect of adding higher amount of reinforcement on agglomeration of zircon particles in Al-MMCs is exhibited in Figs. 4c,d. The amount of unabsorbed particles was grown up with increasing amount of zircon reinforcement, so the porosity volume fraction raised. Zircon agglomeration, dis- 
Table 5. Density variation of aluminium metal matrix composite in comparison to monolithic aluminium

\begin{tabular}{|c|c|c|c|c|c|c|}
\hline Volume fraction of reinforcement & $5 \% \mathrm{~B}_{4} \mathrm{C}$ & $10 \% \mathrm{~B}_{4} \mathrm{C}$ & $15 \% \mathrm{~B}_{4} \mathrm{C}$ & $5 \% \mathrm{ZrSiO}_{4}$ & $10 \% \mathrm{ZrSiO}_{4}$ & $15 \% \mathrm{ZrSiO}_{4}$ \\
\hline Metal matrix composite's density $\left(\mathrm{g} \mathrm{cm}^{-3}\right)$ & 2.680 & 2.679 & 2.677 & 2.688 & 2.690 & 2.693 \\
\hline Increase in density compared to monolithic aluminium & -0.005 & -0.006 & -0.008 & +0.003 & +0.005 & +0.008 \\
\hline
\end{tabular}

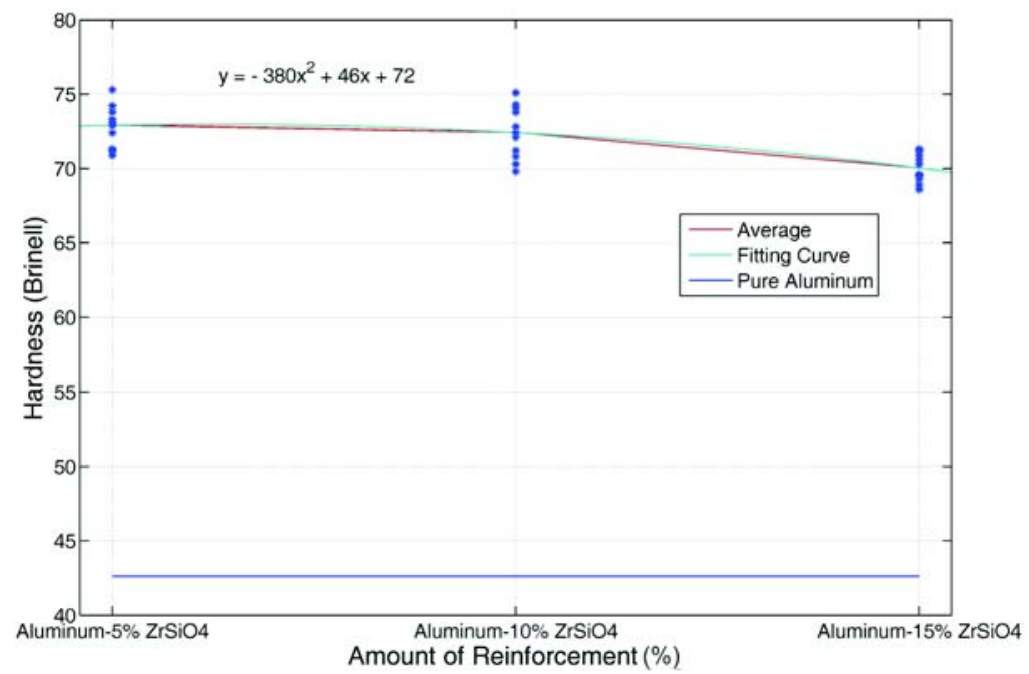

Fig. 6. Hardness variation of $\mathrm{Al}-\mathrm{ZrSiO}_{4}$ composite samples in different amount of zircon at $750{ }^{\circ} \mathrm{C}$.

tortion of aluminium grain boundaries after adding reinforcement, high viscosity and gas arresting would be mentioned as the main reasons for this phenomenon.

\subsection{Study of physical and mechanical behaviour of composite material samples}

The impact of volume fraction of reinforcement on the MMC's density is reported in Table 5. The density of pure aluminium is $2.685 \mathrm{~g} \mathrm{~cm}^{-3}$ and density of $\mathrm{B}_{4} \mathrm{C}$ and $\mathrm{ZrSiO}_{4}$ powders is 2.52 and $4.66 \mathrm{~g} \mathrm{~cm}^{-3}$, respectively. It can concluded that, according to reinforcement density, the composite density is changed and it completely depends on each reinforcement density. Because zircon density is higher than that of pure aluminium, it leads to an increase of the density of composite, while $\mathrm{B}_{4} \mathrm{C}$ has a lower density than aluminium, and so its composite must have a lower density than that of pure aluminium.

Figures 5 and 6 show the influence of amount of reinforcement on the hardness of the composite. The hardness of A356.1 alloy is about $44 \mathrm{HB} . \mathrm{B}_{4} \mathrm{C}$ and $\mathrm{ZrSiO}_{4}$ ceramic phases are much harder than the aluminium alloy. Therefore, according to the rule of mixture, increasing of $\mathrm{B}_{4} \mathrm{C}$ additive enhancing the hardness of the composite and in higher amount of $\mathrm{B}_{4} \mathrm{C}$, the hardness of composite experienced higher grade. Due to the grain size reduction with reinforcement increasing (up to $15 \%$ ), with reinforcement volume fraction increasing, the hardness of $\mathrm{Al}-\mathrm{B}_{4} \mathrm{C}$ specimens is enhanced (Fig. 5). With adding more amount of zircon to aluminium, the hardness of composite samples is decreased because of pore formation in the $\mathrm{ZrSiO}_{4}$ and aluminium matrix interface (Fig. 6).

Figures 7 and 8 show the increased strength of the $\mathrm{A} 356.1-\mathrm{B}_{4} \mathrm{C}$ and $\mathrm{A} 356.1-\mathrm{ZrSiO}_{4}$ composite is ascribed to the synergistic effects of residual stresses produced due to innate discrepancy in thermal expansion coefficients between the composite constituents, strengthening from uptight plastic flow and triaxiality in the soft aluminium metal matrix composite due to the presence of micron ceramic particle reinforcements such as $\mathrm{B}_{4} \mathrm{C}, \mathrm{ZrSiO}_{4}, \mathrm{SiC}, \mathrm{TiB}_{2}, \mathrm{Al}_{2} \mathrm{O}_{3}$. In the case of aluminium alloy-based composites, an addition in the volume fraction of the reinforcing particulates phase may cause an increase in dislocation density and decrease in composite grain size. These microstructural changes tend to grow the endurance offered to the movement of mobile dislocations under the effect of a far-field stress. Hence, an increase in the volume fraction of the reinforcing $\mathrm{B}_{4} \mathrm{C}$ and $\mathrm{ZrSiO}_{4}$ particulates in the aluminium alloy metal matrix would tend to increase the magnitude of endurance offered to the mobility of dislocations.

\section{Conclusions}

1. Applying stir casting method as a low cost method for producing MMCs is successful and it leads 


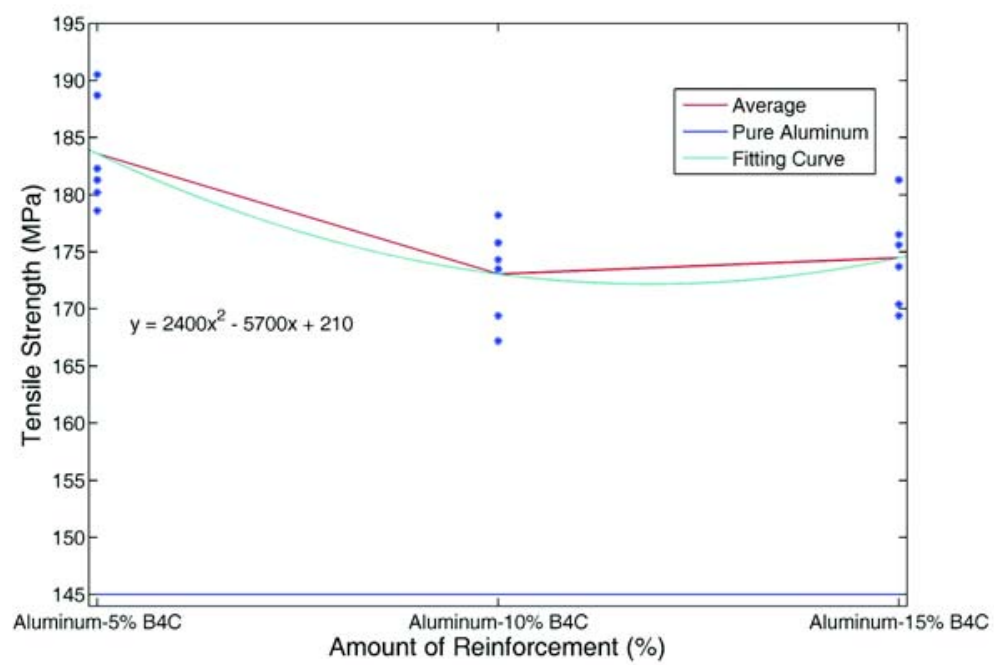

Fig. 7. Ultimate tensile strength variation of $\mathrm{Al}-\mathrm{B}_{4} \mathrm{C}$ composite samples in different amount of $\mathrm{B}_{4} \mathrm{C}$ at $750{ }^{\circ} \mathrm{C}$.

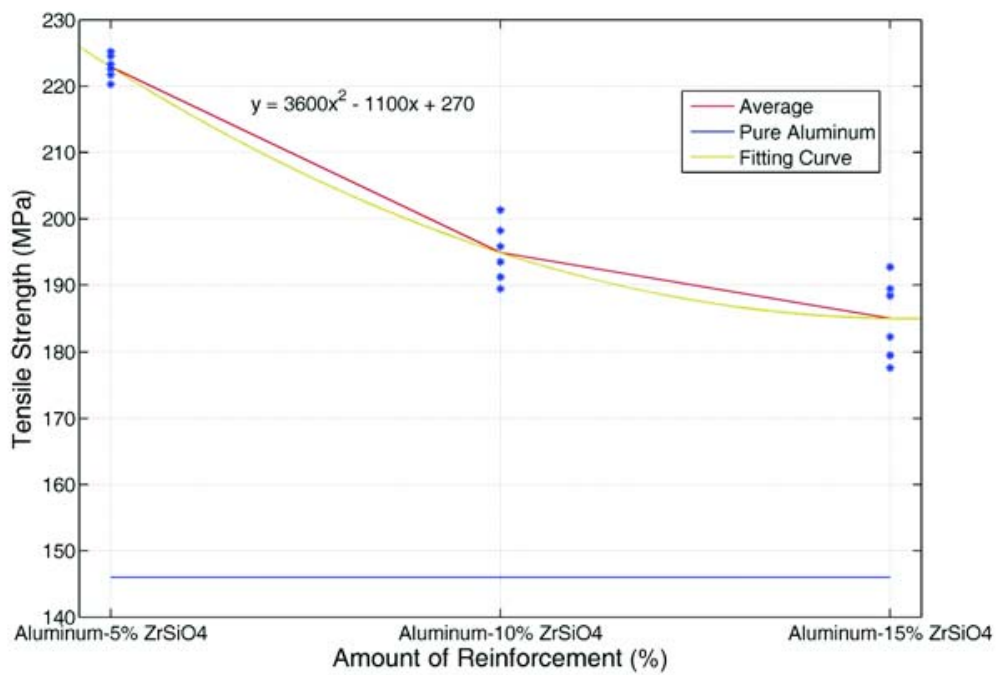

Fig. 8. Tensile strength variation of $\mathrm{Al}-\mathrm{ZrSiO}_{4}$ composite samples in different amount of zircon at $750^{\circ} \mathrm{C}$.

to relatively uniform particle distribution of $\mathrm{B}_{4} \mathrm{C}$ and $\mathrm{ZrSiO}_{4}$ reinforcements.

2. Mechanical properties (hardness and tensile strength) of aluminium matrix composite reinforced by $\mathrm{ZrSiO}_{4}$ and $\mathrm{B}_{4} \mathrm{C}$ are higher than those of the monolithic aluminium due to poor heat expansion coefficient of ceramic particles compared to aluminium that introduce a lot of mismatches at the reinforcement/matrix boundary.

3. Hardness and tensile strength both decrease along with zircon amount increasing above 5 vol.\% in fixed processing temperature due to an increase in porosity and agglomeration of reinforcement, but the

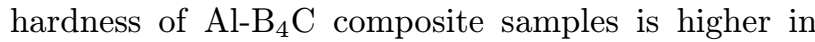
larger amount of reinforcement because of a barrier in dislocation movement. Hardness of $\mathrm{Al}-\mathrm{B}_{4} \mathrm{C}$ composite is higher than that of $\mathrm{Al}-\mathrm{ZrSiO}_{4}$ composites in equal amount of reinforcement because of the differ- ence of mechanism of reinforcement hardness impact on mechanical behaviour of composite samples. Mechanical behaviour of Al-MMC depicts that in higher amount of reinforcement, the percent of agglomeration increased and tensile strength decreased. There is an optimum reinforcement percentage for $\mathrm{Al}^{-\mathrm{B}_{4} \mathrm{C}}$ composite between 5 and 10 vol. $\% \mathrm{~B}_{4} \mathrm{C}$.

4. The effect of adding a second phase on physical property of aluminium base composite shows that density decreased as a result of $\mathrm{B}_{4} \mathrm{C}$ addition to aluminium matrix, because it has a lower density than aluminium. On the contrary, in $\mathrm{Al}-\mathrm{ZrSiO}_{4}$ samples, it leads to enhance the density of composite due to its higher density than that of pure aluminium.

\section{References}

[1] Abdizadeh, H., Baharvandi, H., Shirvani Moghad- 
dam, K.: Mater. Sci. Eng. A, 498, 2008, p. 53. doi:10.1016/j.msea.2008.07.009

[2] Torralba, J. M., da Costa, C. E., Velasco, F.: Mater. Process. Technol., 133, 2003, p. 203. doi:10.1016/S0924-0136(02)00234-0

[3] Zebarjad, S. M., Salladi, S. A.: Mater Design, 28, 2007, p. 2113. doi:10.1016/j.matdes.2006.05.020

[4] Hasson, D. F., Crowe, C. R.: In: Proceeding of 7 th International Conference on the Strength of Metals and Alloys (ICSMA 7). Eds.: McQueen, H. J., Bailon, J.-P., Dickson, J. I. Oxford, Pergamon Press 1985, p. 1515.

[5] Dunand, D. C., Han, B. G., Jansen, A. M.: Metall. Mater. Trans. A, 30, 1999, p. 829. doi:10.1007/s11661-999-1016-6

[6] Liaw, P. K., Greggi, H. G., Logsdon, W. A.: Mater. Sci. Lett., 22, 1987, p. 1613. doi:10.1007/BF01132381

[7] Karbalaei Akbari, M., Mirzaee, O., Baharvandi, H. R.: Mater and Design, 46, 2013, p. 199. doi:10.1016/j.matdes.2012.10.008

[8] Grade, D. H., Mandell, J. F., Hong, K. C. C.: Mater Sci, 23, 1988, p. 311. doi:10.1007/BF01174071

[9] Niskanen, P., Mohn, W. R.: Adv. Mater. and Process., 133, 1988, p. 39.

[10] Zedalis, M. S., Bryant, J. D., Gilman, P. S., Das, S. K.: Metals, 29, 1991, p. 341.

[11] Fernandez, R., Gonzalez-Doncel, G.: Scripta Mater., 59, 2008, p. 1135. doi:10.1016/j.scriptamat.2008.07.038

[12] Edward, G. H., Ashby, M. F.: Acta Mater., 27, 1979, p. 1505. doi:10.1016/0001-6160(79)90173-1

[13] Davanas, K., Salomon, A. A.: Acta Metal. Mater., 38, 1990, p. 1905. doi:10.1016/0956-7151(90)90302-W

[14] Srivatsan, T. S., Sudarshan, T. S., Lavernia, E. J.: Prog in Mat Sci., 39, 1995, p. 317. doi:10.1016/0079-6425(95)00003-8

[15] Manoharan, M., Lewandowski, J. J.: Acta Metal. Mater., 38, 1990, p. 1. doi:10.1016/0956-7151(90)90155-A
[16] Lloyd, D. J.: Int Mater Rev., 39, 1994, p. 1. doi:10.1179/imr.1994.39.1.1

[17] McDanels, D. L.: Metal Trans. A, 16, 1985, p. 1105. doi:10.1007/BF02811679

[18] Dermarkar, S.: Metal and Mater. Int., 2, 1986, p. 144.

[19] Nieh, T. G., Karlak, R. F.: Scripta Metall., 18, 1984, p. 25. doi:10.1016/0036-9748(84)90083-8

[20] Viala, J. C., Bouix, J., Gonzalez, G., Esnouf, C.: Mater. Sci., 32, 1997, p. 4559. doi:10.1023/A:1018625402103

[21] Pyzik, A. J., Beaman, D. R.: J. Am. Ceram. Soc., 78, 1994, p. 305. doi:10.1111/j.1151-2916.1995.tb08801.x

[22] Hanumanth, G. S., Irons, G. A.: Mater. Sci., 28, 1993, p. 2459. doi:10.1007/BF01151680

[23] Lee, C. S., Kim, T. H., Han, K. S., Lim, L.: Mater. Sci., 27, 1992, p. 793. doi:10.1007/BF02403898

[24] McDanels, D. L.: Metal. Trans. A, 16, 1985, p. 1105. doi:10.1007/BF02811679

[25] Alpas, A. T., Zhang, J.: Scripta Metal. Mater, 26, 1992, p. 505. doi:10.1016/0956-716X(92)90638-U

[26] Akbulut, H., Durman, M., Yilmaz, F.: Wear, 215, 1998, p. 170. doi:10.1016/S0043-1648(97)00237-8

[27] Delannay, F., Froyen, L., Deruytter, A.: Mater. Sci., 22, 1987, p. 1. doi:10.1007/BF01160545

[28] Rajan, T. P. D., Pillai, R. M., Pai, B. C.: Mater. Sci., 33, 1998, p. 3491. doi:10.1023/A:1004674822751

[29] Valiev, R. Z., Enikeev, N. A., Langdon, T. G.: Kovove Mater., 49, 2011, p. 1.

[30] Kang, C. G., Yoon, J. H., Seo, Y. H.: Mater. Proc. Technol., 66, 1997, p. 30. doi:10.1016/S0924-0136(96)02493-4

[31] Skolianos, S.: Mater. Sci. Eng. A, 210, 1996, p. 76. doi:10.1016/0921-5093(95)10043-1

[32] Skolianos, S., Kattamis, T. Z.: Mater. Sci. Eng. A, 163, 1993, p. 107. doi:10.1016/0921-5093(93)90584-2

[33] Han, N., Pollard, G., Stevens, R.: Mat. Sci. Letters, 11, 1992, p. 944. doi:10.1007/BF00729102 